University of New Hampshire

University of New Hampshire Scholars' Repository

\title{
Women's risk perception and sexual victimization: A review of the literature
}

Christine A. Gidycz

Ohio University - Main Campus

John R. McNamara

Ohio University - Main Campus

Katie M. Edwards

University of New Hampshire, katie.edwards@unh.edu

Follow this and additional works at: https://scholars.unh.edu/psych_facpub

\section{Recommended Citation}

Christine A. Gidycz, John R. McNamara, Katie M. Edwards, Women's risk perception and sexual victimization: A review of the literature, Aggression and Violent Behavior, Volume 11, Issue 5, September-October 2006, Pages 441-456, ISSN 1359-1789, http://dx.doi.org/10.1016/j.avb.2006.01.004.

This Article is brought to you for free and open access by the College of Liberal Arts (COLA) at University of New Hampshire Scholars' Repository. It has been accepted for inclusion in Psychology Scholarship by an authorized administrator of University of New Hampshire Scholars' Repository. For more information, please contact Scholarly.Communication@unh.edu. 


\title{
Women's risk perception and sexual victimization: A review of the literature
}

\author{
Christine A. Gidycz *, John R. McNamara, Katie M. Edwards \\ 231 Porter Hall, Department of Psychology, Ohio University, Athens, OH 45701, USA \\ Received 19 July 2005; received in revised form 12 September 2005; accepted 10 January 2006 \\ Available online 28 February 2006
}

\begin{abstract}
This article reviews empirical and theoretical studies that examined the relationship between risk perception and sexual victimization in women. Studies examining women's general perceptions of risk for sexual assault as well as their ability to identify and respond to threat in specific situations are reviewed. Theoretical discussions of the optimistic bias and cognitive-ecological models of risk recognition are discussed in order to account for findings in the literature. Implications for interventions with women as well as recommendations for future research are provided.
\end{abstract}

(C) 2006 Elsevier Ltd. All rights reserved.

Keywords: Women's risk perception; Sexual victimization; Literature review

\section{Contents}

1. Introduction . . . . . . . . . . . . . . . . . . . . . . . . . . . . . . . 442

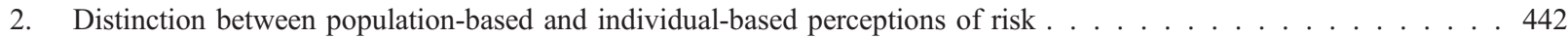

2.1. Summary of the evidence. . . . . . . . . . . . . . . . . . . . . . . . 442

2.2. Hypothesized mechanisms related to distinctions in global and specific risk perceptions. . . . . . . . . . 444

3. Summary of evidence suggesting that sexual victimization is related to deficits in risk perceptions. . . . . . . . . 444

3.1. Evidence suggesting victimized women possess deficits in risk recognition skills . . . . . . . . . . . 444

3.2. Evidence suggesting that victimized women do not possess deficits in risk recognition . . . . . . . . . . 446

3.3. Explanations for inconsistencies . . . . . . . . . . . . . . . . . . . . . . . . 447

4. The relationship between situational factors and risk recognition . . . . . . . . . . . . . . . . . 448

4.1. Alcohol use . . . . . . . . . . . . . . . . . . . . . . . . . . . . . 448

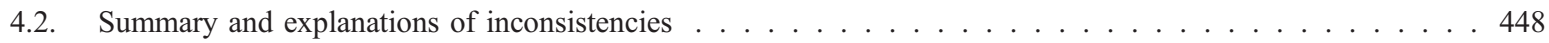

4.3. Relationship between victim and perpetrator . . . . . . . . . . . . . . . . . . . . . . 449

5. Theoretical explanations of risk recognition and sexual assault $\ldots \ldots \ldots \ldots \ldots \ldots \ldots \ldots$

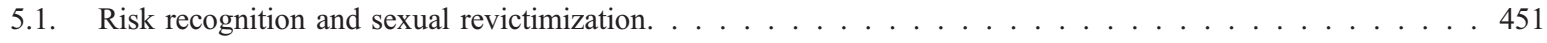

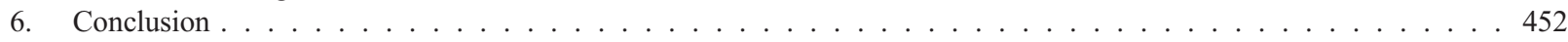

6.1. Implications for intervention . . . . . . . . . . . . . . . . . . . . . . . 452

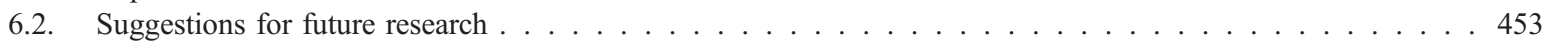

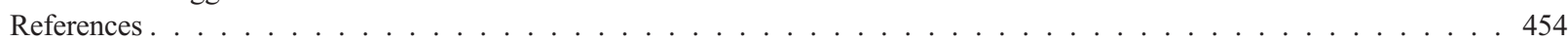

* Corresponding author. Tel.: +1 740593 1092; fax: +1 7405930579.

E-mail address: gidycz@ohio.edu (C.A. Gidycz). 


\section{Introduction}

Sexual assault is an endemic problem in our society. Investigations with college students have consistently documented that approximately $15-20 \%$ of women have experienced a rape or attempted rape at some time in their lives (Brener, McMahon, Warren, \& Douglas, 1999; Koss, Gidycz, \& Wisniewski, 1987). Longitudinal studies suggest that between $16 \%$ and $18 \%$ of college women experienced some form of sexual victimization over brief three- to sixmonth periods (Gidycz, Hanson, \& Layman, 1995; Gidycz, Rich, King, Orchowski, \& Miller, in press). These estimates from college student samples are remarkably consistent with those obtained from large-scale community samples of women (Brecklin \& Ullman, 2002; Tjaden \& Thoennes, 2000). Tjaden and Thoennes (2000) conducted a nationally representative telephone survey and found that approximately $15 \%$ of the participants indicated that they had been forced to have sex. Across university and community samples it has also been found that the vast majority of assaults are perpetrated by acquaintances (e.g., Brener et al., 1999; Tjaden \& Thoennes, 2000; VanZile-Tamsen, Testa, \& Livingston, 2005).

Certain variables place women at higher risk for assault (see Rich, Combs-Lane, Resnick, \& Kilpatrick, 2004 for a review), and one such variable, risk recognition ability, has received an increasing amount of attention in the empirical literature. Whereas offenders are clearly responsible for all acts of sexual aggression and preventative efforts with men should be a priority, ethically it is essential that women be provided with the information and skills to reduce their risk for sexual assault. It follows that early identification of risk should lead to increased resistance and self-protective behaviors (Norris, Nurius, \& Dimeff, 1996; VanZile-Tamsen et al., 2005) which is one of the major objectives of risk reduction programming with women (Gidycz, Rich et al., in press).

Within this growing body of literature, there seem to be two different levels of risk recognition. The first level pertains to a more general estimate of perceived vulnerability, whereas the second level pertains to recognition of situational risk. With regard to perceived vulnerability, researchers have noted the importance of distinguishing between population- and individual-based risk perceptions (Nurius, 2000). Norris, Nurius, and Graham (1999) suggested that an individual might possess a general awareness that women are at risk to be sexually victimized, without relating those perceptions to one's own life experiences.

The empirical evidence continues to be quite conflicting as to situational risk recognition. Some research suggests that delayed risk recognition puts women at higher risk for sexual assault (Marx, Calhoun, Wilson, \& Meyerson, 2001; Soler-Baillo, Marx, \& Sloan, 2005; Wilson, Calhoun, \& Bernat, 1999). However, other researchers argued that the crucial issue is not so much delayed risk recognition, as it is unassertive behavioral response to a sexual assault situation (Breitenbecher, 1999; Messman-Moore \& Brown, in press; Naugle, 2000; VanZile-Tamsen et al., 2005). There is also conflicting evidence on alcohol use and risk recognition. Results of several studies suggested that alcohol does impair risk recognition (Davis, 2000; Testa, Livingston, \& Collins, 2000), whereas others have found no such relationship (Cue, George, \& Norris, 1996; Livingston \& Testa, 2000). Additionally, it does appear that risk recognition might be most difficult in situations where the offender is known to the victim, in that in such settings romantic cues that are quite salient often conflict with less obvious cues indicative of sexual assault risk (e.g., Norris et al., 1999).

In light of this growing body of literature and the inconsistencies across studies, a review article is warranted. This article will summarize the risk recognition and sexual assault literature and attempt to offer some explanations for inconsistencies across studies. Recent theoretical frameworks that have been proposed to help explain the correlates of risk recognition will be discussed, as well as implications for interventions and future research.

\section{Distinction between population-based and individual-based perceptions of risk}

\subsection{Summary of the evidence}

Researchers have noted the importance of distinguishing between global (population-based) and specific (individual-based) perceptions of risk for sexual assault (Norris et al., 1996, 1999). Women are aware that sexual assault occurs, but they believe that they are at a lower risk to be victimized than their peers. In fact, Norris et al. (1999) found that global perceptions of risk in college women were not related to judgments pertaining to specific situational risks (see Table 1 for a summary of relevant studies).

To date, there have been five empirical investigations that have explored women's perceptions of risk relative to others. The four studies that were conducted with college students were consistent in that women underestimated their 
Table 1

Summary of studies examining perceived vulnerability to sexual assault

\begin{tabular}{|c|c|c|c|c|}
\hline Authors & Sample and design & Victimization definition & Variables $^{\mathrm{a}}$ & Findings \\
\hline $\begin{array}{l}\text { Brown, Messman- } \\
\text { Moore, Miller, } \\
\text { and Stasser (2005) }\end{array}$ & $\begin{array}{l}268 \text { university } \\
\text { women; mean } \\
\text { age }=19.18 \\
\text { Prospective }\end{array}$ & $\begin{array}{l}\text { Contact, coercion, } \\
\text { attempted and } \\
\text { completed rape } \\
\text { after age } 17\end{array}$ & $\begin{array}{l}\text { Sexual Experience Survey } \\
\text { (SES); Risk Judgments, } \\
\text { Perceived Similarity to Victim, } \\
\text { and Perceived Control } \\
\text { Questionnaire (measure } \\
\text { developed for current study) }\end{array}$ & $\begin{array}{l}\text { Women with more severe victimization } \\
\text { histories perceived themselves more } \\
\text { vulnerable to future sexual assault; this } \\
\text { relationship mediated by perceived } \\
\text { similarity to a typical victim; victimization } \\
\text { history was not related to comparative risk } \\
\text { judgments }\end{array}$ \\
\hline Bryant (2001) & $\begin{array}{l}493 \text { university } \\
\text { women; } 90 \% \text { were } \\
18 \text { or } 19 \text { years old; } \\
\text { Prospective }\end{array}$ & $\begin{array}{l}\text { Any type of sexual } \\
\text { victimization } \\
\text { in childhood } \\
\text { or adolescence }\end{array}$ & $\begin{array}{l}\text { SES; Child Sexual } \\
\text { Victimization Questionnaire; } \\
\text { Perceived Vulnerability to } \\
\text { Sexual Victimization, } \\
\text { Self-efficacy Scale }\end{array}$ & $\begin{array}{l}\text { History of sexual victimization predicted } \\
\text { women feeling more vulnerable to future } \\
\text { sexual assault and lower levels of self- } \\
\text { efficacy regarding their ability to deal with } \\
\text { a risky situation }\end{array}$ \\
\hline $\begin{array}{l}\text { Cue, George, } \\
\text { and Norris (1996) }\end{array}$ & $\begin{array}{l}165 \text { university } \\
\text { women; mean } \\
\text { age }=20.4 \\
\text { Retrospective }\end{array}$ & N/A & $\begin{array}{l}\text { Feelings Questionnaire } \\
\text { adapted from the Subjective } \\
\text { Perceptions Form }\end{array}$ & $\begin{array}{l}\text { Compared to their peers, women } \\
\text { considered themselves to be at lower risk } \\
\text { than other women to experience sexual } \\
\text { assault }\end{array}$ \\
\hline $\begin{array}{l}\text { Hickman and } \\
\text { Muehlenhard } \\
\text { (1997) }\end{array}$ & $\begin{array}{l}139 \text { university } \\
\text { women; mean } \\
\text { age }=19 ; \\
\text { Retrospective }\end{array}$ & $\mathrm{N} / \mathrm{A}$ & $\begin{array}{l}\text { All questions were created for } \\
\text { this study, including how likely } \\
\text { they were to be raped and how } \\
\text { likely college women were to } \\
\text { be raped }\end{array}$ & $\begin{array}{l}\text { Women indicated that they were less likely } \\
\text { than average college women to be raped by } \\
\text { either a stranger or an acquaintance }\end{array}$ \\
\hline $\begin{array}{l}\text { Norris, Nurius, } \\
\text { and Dimeff (1996) }\end{array}$ & $\begin{array}{l}66 \text { sorority } \\
\text { women; mean } \\
\text { age }=19.2 \\
\text { Retrospective }\end{array}$ & $\begin{array}{l}\text { Attempted or completed } \\
\text { rape within the past year }\end{array}$ & $\begin{array}{l}\text { Modified version of the SES; } \\
\text { Perceived risk of sexual } \\
\text { victimization based on SES }\end{array}$ & $\begin{array}{l}\text { Women had high awareness of sexual } \\
\text { assault and preventative measures other } \\
\text { women should take, but said that they } \\
\text { would not put themselves in a risky } \\
\text { situation; victimized women reported } \\
\text { higher likelihood of future assault than } \\
\text { women without such histories }\end{array}$ \\
\hline $\begin{array}{l}\text { Norris, Nurius, } \\
\text { and Graham (1999) }\end{array}$ & $\begin{array}{l}152 \text { university } \\
\text { women; mean } \\
\text { age }=20.3 \text {; } \\
\text { Retrospective }\end{array}$ & $\begin{array}{l}\text { CSA (dichotomous yes/ } \\
\text { no question asking if } \\
\text { experienced child } \\
\text { sexual abuse) and ASA } \\
\text { (contact, coercion, } \\
\text { attempted and } \\
\text { completed rape) }\end{array}$ & $\begin{array}{l}\text { SES; Situational Risk Factors } \\
\text { and Global Perceptions of Risk } \\
\text { Survey (created for this study) }\end{array}$ & $\begin{array}{l}\text { Compared to their peers, women } \\
\text { considered themselves to be at lower risk } \\
\text { to experience sexual assault; global } \\
\text { perceptions of risk not related to judgments } \\
\text { pertaining to situational risk; women with } \\
\text { adult victimization histories perceived } \\
\text { themselves more vulnerable to experience } \\
\text { sexual assault than nonvictims }\end{array}$ \\
\hline $\begin{array}{l}\text { Parks, Miller, Collins, } \\
\text { and Zetes-Zanatta } \\
\text { (1998) }\end{array}$ & $\begin{array}{l}52 \text { community } \\
\text { women who } \\
\text { regularly drank in } \\
\text { bars; mean } \\
\text { age }=31.9 ; \\
\text { Retrospective }\end{array}$ & N/A & $\begin{array}{l}\text { Qualitative interviews } \\
\text { and group discussions }\end{array}$ & $\begin{array}{l}\text { Women recognized that bars were risky } \\
\text { places, but they believed that they were less } \\
\text { vulnerable and better able to handle risks } \\
\text { than other women }\end{array}$ \\
\hline
\end{tabular}

Summary of abbreviations: $\mathrm{CSA}=$ childhood sexual abuse, ASA= adult sexual assault.

${ }^{a}$ Other measures may have been used in the studies. However, for the purposes of this chart, only measures relevant to perceived vulnerability were included.

risk for sexual assault relative to their peers (Cue et al., 1996; Hickman \& Muehlenhard, 1997; Norris et al., 1996, 1999). In an initial focus group study, the sample of sorority women of Norris et al. (1996) had a relatively high general awareness of sexual assault and preventative measures that other women should take. These women, however, reportedly felt that they were different from other women in that they would not be "dumb enough" to get into a risky situation in the first place. Similarly, when asked specifically about their likelihood of being raped relative to their peers, Hickman and Muehlenhard (1997) reported that their group of women indicated that they were less likely than the average college women to be raped by either a stranger or an acquaintance. In two studies that utilized vignettes, it was further found that woman considered themselves to be at a lower risk than other women to experience sexual assault (Cue et al., 1996; Norris et al., 1999). Unlike other studies, Parks, Miller, Collins, and Zetes-Zanatta (1998) 
utilized a community sample. Women who drank regularly in bars participated in their focus group study. Results suggested that although women generally recognized that bars were risky places, they believed that they were less vulnerable and better able to handle risks than other women.

Thus, there seems to be a consensus in the literature that women, in general, feel at low risk for sexual assault victimization, especially relative to their peers. However, it is important to note that this is not necessarily the case for women with victimization histories. In fact, several studies have documented that previously victimized women viewed their risk of a future sexual assault as higher than did women without such histories (Bryant, 2001; Norris et al., 1996; Nurius, Norris, Dimeff, \& Graham, 1996). Overall, however, women tend to view their risk of experiencing a sexual assault as minimal.

\subsection{Hypothesized mechanisms related to distinctions in global and specific risk perceptions}

Obviously, it is important that women be cognizant of their risk of being sexually assaulted so that they can engage in precautionary behaviors. Accordingly, it is important to understand the underlying mechanisms responsible for women's apparent feelings of invulnerability. Our interpretations of our experiences are often the result of cognitive biases. This phenomenon is especially important within the context of risk perception and the notion of comparative optimism or unique invulnerability (Hickman \& Muehlenhard, 1997; Weinstein, 1980; Weinstein \& Klein, 1995) because these cognitive biases likely contribute to women's sexual assault risk.

Weinstein (1987) suggested that comparative optimism refers to the tendency for people to believe that they are more likely than others to experience positive events, and less like to experience negative events. The tendency for people to believe that they are more likely to experience positive events does not necessarily lead to negative consequences. In fact, in many instances, it leads to enhanced well-being. However, when people believe that they are less likely to experience negative events, it is likely to result in risky behavior or a failure to take precautions (Shepperd, Carroll, Grace, \& Terry, 2002). Thus, individuals who possess such cognitive distortion are less likely to engage in precautionary behaviors and are therefore at increased risk to experience a negative event. This is likely the case for many women who do not believe that they are at risk for sexual assault. Although risk reduction programs should not instill fear in women, it seems important that women be cognizant of their risk of experiencing a sexual assault and plan precautionary behaviors and effective resistance strategies accordingly.

The findings suggesting that women with sexual victimization histories perceive themselves to be at greater risk for sexual assault than women without such histories are consistent with the broader trauma literature. More specifically, research investigating other types of traumas suggests that personal experience with a particular type of negative event decreases the optimistic bias (Weinstein, Lyon, Rothman, \& Cuite, 2000). Helweg-Larsen and Shepperd (2001) suggest that this increase in risk perception is due to the fact that trauma-exposed individuals identify more readily with the victim role, possess negative affective states such as depression and anxiety, and perceive a decreased sense of control and increased sense of vulnerability. In a study that assessed sexual trauma in particular, Brown, Messman-Moore, Miller, and Stasser (2005) found that victimized women's perceived similarity to a typical victim and psychological distress were both related to increased perceptions of risk for a sexual assault.

\section{Summary of evidence suggesting that sexual victimization is related to deficits in risk perceptions}

Although the evidence is fairly clear that women in general perceive themselves as less likely than their peers to be sexually assaulted, the data are somewhat mixed regarding the relationship between victimization status and their ability to recognize risk in specific situations (See Table 2 for a summary of relevant studies).

\subsection{Evidence suggesting victimized women possess deficits in risk recognition skills}

Two retrospective studies of women with abuse histories suggested that these women have difficulties identifying risk in potentially threatening situations. Both of these studies used an audio-taped vignette depicting an interaction between a man and a woman that ultimately escalates into a rape (Marx \& Gross, 1995). Participants were asked to stop the tape when they believed that the man had "gone too far." In the comparison of Wilson et al. (1999) of single- and multiple-incident victims, and non-victims, results suggested that multiple-incident victims had longer response latencies (suggesting delays in recognizing risk) than either the single-incident or non-victims. Additionally, 
Table 2

Summary of studies examining situational risk recognition

\begin{tabular}{|c|c|c|c|c|c|}
\hline Authors & Sample and design & Victimization definition & Variables $^{\mathrm{a}}$ & Vignette description & Findings \\
\hline $\begin{array}{l}\text { Breitenbecher } \\
\text { (1999) }\end{array}$ & $\begin{array}{l}224 \text { university } \\
\text { women at Time } \\
1 ; 66 \text { returned } 5 \\
\text { months later at } \\
\text { Time } 2 ; 81 \% \\
\text { were } 18-21 \text { years } \\
\text { old; Prospective }\end{array}$ & $\begin{array}{l}\text { CSA (exhibitionism, } \\
\text { fondling, attempted } \\
\text { and completed rape) } \\
\text { or ASA (contact, } \\
\text { coercion, attempted } \\
\text { and completed rape) }\end{array}$ & $\begin{array}{l}\text { Childhood Sexual Abuse } \\
\text { Questionnaire (CSAQ); } \\
\text { Modified Sexual Experience } \\
\text { Survey (SES); Threat } \\
\text { Perception } \\
\text { Questionnaire; videotaped } \\
\text { vignette }\end{array}$ & $\begin{array}{l}\text { Two videotaped vignettes; } \\
\text { one acquaintance rape with } \\
\text { multiple risk-related } \\
\text { variables; the other } \\
\text { romantic, with no rape and } \\
\text { only one risk-related } \\
\text { variable. Both contain } \\
\text { college-aged, heterosexual } \\
\text { couple }\end{array}$ & $\begin{array}{l}\text { Victimization at both Time } \\
1 \text { and Time } 2 \text { were not } \\
\text { related to risk recognition } \\
\text { as measured by responses } \\
\text { to the videotape at Time } 1\end{array}$ \\
\hline $\begin{array}{l}\text { Marx, } \\
\text { Calhoun, } \\
\text { Wilson, and } \\
\text { Meyerson } \\
\text { (2001) }\end{array}$ & $\begin{array}{l}66 \text { university } \\
\text { women; mean } \\
\text { age }=20 ; \\
\text { Prospective }\end{array}$ & $\begin{array}{l}\text { Coercion, attempted } \\
\text { or completed rape } \\
\text { after age } 14\end{array}$ & SES; audiotaped vignette & $\begin{array}{l}\text { Marx and Gross (1995) } \\
\text { audiotaped vignette; } \\
\text { date rape encounter; } \\
\text { multiple risk-related } \\
\text { variables; clear } \\
\text { resistance of woman }\end{array}$ & $\begin{array}{l}\text { Women raped over the } \\
\text { follow-up period displayed } \\
\text { longer response latencies } \\
\text { at Time } 1 \text {, indicative of } \\
\text { poorer risk recognition }\end{array}$ \\
\hline $\begin{array}{l}\text { Messman- } \\
\text { Moore and } \\
\text { Brown } \\
\text { (in press) }\end{array}$ & $\begin{array}{l}262 \text { university } \\
\text { women; mean } \\
\text { age }=19.18 ; \\
\text { Prospective }\end{array}$ & $\begin{array}{l}\text { CSA (any contact } \\
\text { prior to age 17) } \\
\text { and ASA (any } \\
\text { unwanted sexual } \\
\text { contact after age 17) }\end{array}$ & $\begin{array}{l}\text { SES; Risk Perception } \\
\text { Survey (written vignette) }\end{array}$ & $\begin{array}{l}\text { Two written vignettes; } \\
\text { both ended with rape; one } \\
\text { acquaintance in social } \\
\text { setting; the other stranger } \\
\text { in non-social setting; both } \\
\text { included clear risk factors } \\
\text { and ambiguous risk } \\
\text { factors; participants } \\
\text { indicated when they were } \\
\text { uncomfortable and when } \\
\text { they would leave }\end{array}$ & $\begin{array}{l}\text { CSA not associated with } \\
\text { risk recognition; } \\
\text { victimization history did } \\
\text { not affect risk recognition } \\
\text { ability; decision to leave } \\
\text { hypothetical situation } \\
\text { predicted victimization } \\
\text { over the interim, but risk } \\
\text { recognition did not }\end{array}$ \\
\hline Naugle (2000) & $\begin{array}{l}80 \text { university } \\
\text { women; mean } \\
\text { age }=20.83 ; \\
\text { Retrospective }\end{array}$ & $\begin{array}{l}\text { CSA (contact and } \\
\text { attempted and } \\
\text { completed intercourse } \\
\text { prior to age 14) and } \\
\text { ASA (attempted or } \\
\text { completed rape after } \\
\text { age 14) }\end{array}$ & $\begin{array}{l}\text { Wyatt Sexual History } \\
\text { Questionnaire; SES; } \\
\text { National Women's Study } \\
\text { Victimization Screening; } \\
\text { videotaped vignettes }\end{array}$ & $\begin{array}{l}\text { Three videotaped-taped } \\
\text { vignettes; one depicts } \\
\text { coercion between student } \\
\text { and teacher; the second } \\
\text { depicts a newly acquainted } \\
\text { male and female who have } \\
\text { a drink together and ends } \\
\text { with the male offering } \\
\text { female ride home; the third } \\
\text { depicts acquaintances at } \\
\text { college party and ends } \\
\text { with male asking female to } \\
\text { go into bedroom; none } \\
\text { explicitly depict sexual } \\
\text { assault }\end{array}$ & $\begin{array}{l}\text { Victims rated all three } \\
\text { vignettes as riskier, but } \\
\text { were more likely than } \\
\text { nonvictims to comply with } \\
\text { the risky situation }\end{array}$ \\
\hline $\begin{array}{l}\text { Soler-Baillo, } \\
\text { Marx, and } \\
\text { Sloan } \\
(2005)\end{array}$ & $\begin{array}{l}98 \text { university } \\
\text { women; mean } \\
\text { age }=19.55 ; \\
\text { Retrospective }\end{array}$ & $\begin{array}{l}\text { Unwanted sex play, } \\
\text { attempted or completed } \\
\text { rape after age } 14\end{array}$ & $\begin{array}{l}\text { SES; audiotaped } \\
\text { vignette; physiological } \\
\text { measures }\end{array}$ & $\begin{array}{l}\text { Marx and Gross (1995) } \\
\text { audiotaped vignette }\end{array}$ & $\begin{array}{l}\text { Victims of sexual assault } \\
\text { displayed longer response } \\
\text { latencies to vignette and } \\
\text { less automatic reactivity to } \\
\text { critical risk recognition } \\
\text { period in vignette }\end{array}$ \\
\hline $\begin{array}{l}\text { VanZile- } \\
\text { Tamsen, } \\
\text { Testa, and } \\
\text { Livingston } \\
\text { (2005) }\end{array}$ & $\begin{array}{l}318 \text { community } \\
\text { women; mean } \\
\text { age }=23.97 \\
\text { Retrospective }\end{array}$ & $\begin{array}{l}\text { CSA (exposure, kissing/ } \\
\text { touching, attempted or } \\
\text { completed rape before } \\
\text { age 14) and ASA } \\
\text { (contact, coercion, } \\
\text { attempted or completed } \\
\text { rape after age 14) }\end{array}$ & $\begin{array}{l}\text { CSA compilation of } \\
\text { Finkelhor (1979) and } \\
\text { Whitmire, Harlow, Quina, } \\
\text { and Morokoff (1999); SES; } \\
\text { Sexual Assertiveness Scale; } \\
\text { Behavioral Intentions } \\
\text { (adapted from Norris, } \\
\text { George, Stoner, and Masters, } \\
\text { 2002); written vignette and } \\
\text { risk appraisal scale }\end{array}$ & $\begin{array}{l}3 \text { written vignettes; all the } \\
\text { same scenario except that } \\
\text { the perpetrator varies in } \\
\text { each - a male friend, a } \\
\text { date, or a boyfriend; sexual } \\
\text { advances escalate, ending } \\
\text { with the perpetrator } \\
\text { pushing the female on } \\
\text { the bed }\end{array}$ & $\begin{array}{l}\text { Victimization status had no } \\
\text { effect on risk recognition } \\
\text { in any of the scenarios; } \\
\text { women with victimization } \\
\text { histories were lower in } \\
\text { sexual refusal } \\
\text { assertiveness and reported } \\
\text { that they would be less } \\
\text { likely to use active forms } \\
\text { of resistance }\end{array}$ \\
\hline
\end{tabular}


Table 2 (continued)

\begin{tabular}{|c|c|c|c|c|c|}
\hline Authors & Sample and design & Victimization definition & Variables $^{\mathrm{a}}$ & Vignette description & Findings \\
\hline $\begin{array}{l}\text { Wilson, } \\
\text { Calhoun, } \\
\text { and Bernat } \\
\text { (1999) }\end{array}$ & $\begin{array}{l}330 \\
\text { university women; } \\
\text { mean age=19.48; } \\
\text { Retrospective }\end{array}$ & $\begin{array}{l}\text { CSA } \\
\text { (attempted or completed } \\
\text { sexual contact) and } \\
\text { ASA (attempted or } \\
\text { completed rape after } \\
\text { age 14) }\end{array}$ & $\begin{array}{l}\text { CSAQ; SES; } \\
\text { Modified PTSD } \\
\text { Symptom Scale-Self- } \\
\text { Report; audiotaped } \\
\text { vignette }\end{array}$ & $\begin{array}{l}\text { Marx and Gross (1995) } \\
\text { audiotaped vignette }\end{array}$ & $\begin{array}{l}\text { Multiple-incident victims } \\
\text { had longer response } \\
\text { latencies than single- } \\
\text { incident or nonvictims; } \\
\text { revictimized women with } \\
\text { longer response latencies } \\
\text { had lower PTSD arousal } \\
\text { symptoms than } \\
\text { revictimized women with } \\
\text { shorter response latencies }\end{array}$ \\
\hline $\begin{array}{l}\text { Yeater and } \\
\text { O’Donohue } \\
\text { (2002) }\end{array}$ & $\begin{array}{l}300 \text { university } \\
\text { women; mean } \\
\text { age }=23.5 ; \\
\text { Retrospective }\end{array}$ & $\begin{array}{l}\text { CSA (any sexual } \\
\text { coercion before age 14) } \\
\text { and ASA (any sexual } \\
\text { coercion after age 14) }\end{array}$ & $\begin{array}{l}\text { Childhood Sexual } \\
\text { Experience Questionnaire; } \\
\text { SES; Risk Factors and Risk } \\
\text { Perception (written vignette) }\end{array}$ & $\begin{array}{l}\text { Two written vignettes; } \\
\text { both escalated to rape; } \\
\text { one acquaintance; the } \\
\text { other stranger }\end{array}$ & $\begin{array}{l}\text { Single-incident victims } \\
\text { took significantly longer } \\
\text { than nonvictims and } \\
\text { multiple-incident victims } \\
\text { to be trained to recognize } \\
\text { risk }\end{array}$ \\
\hline
\end{tabular}

Summary of abbreviations: CSA= childhood sexual abuse, ASA=adult sexual assault.

${ }^{a}$ Other variables may have been used in the study. However, for the purposes of this chart, only measures relevant to situational risk recognition were included.

revictimized women with longer response latencies reported significantly lower posttraumatic stress disorder (PTSD) arousal symptoms than did revictimized women with shorter response latencies.

In a subsequent study, which compared women with an adult victimization to non-victims, Soler-Baillo et al. (2005) found that past victims demonstrated longer response latencies than women without victimization histories. Interestingly, in this investigation, victims also evidenced attenuated heart rate activity, relative to the non-victims, during the segment of the audiotape most pertinent to risk recognition.

Yeater and O'Donohue (2002) utilized a slightly different experimental design to assess victimization status and situational risk recognition in a sample of undergraduate women. In this retrospective study, these researchers examined the length of time it took to train women with single, multiple, and no sexual assault histories to recognize risk in a written vignette. Results suggested that revictimized women did not take longer to be trained on the criterion material than did non-victims or single-incident assault victims. Rather, results suggested that single-incident assault victims took significantly longer than did non-victims and revictimzed women to be trained to recognize risk. Yeater and O'Donohue (2002) noted that women with multiple assault histories may be better at differentiating risk than single assault victims. This study found results quite the opposite of the studies discussed in this section. (Soler-Baillo et al., 2005; Wilson et al., 1999). It is important to note that the Yeater and O'Donohue's (2002) study utilized a written vignette and measured the time it took to train individuals, not their original response latency. Further, all three investigations (Soler-Baillo et al., 2005; Wilson et al., 1999; Yeater \& O’Donohue, 2002) are limited by the retrospective nature of the design. Thus, it is not clear whether potential differences in risk recognition preceded or were a result of the victimization experience.

As part of a larger study investigating effectiveness of a sexual assault risk reduction program, Marx et al. (2001) had participants respond to the Marx and Gross (1995) audiotape at the beginning of the study. Two-months later, rates of victimization were assessed and it was found that women who were raped during this brief follow-up period evidenced longer response latencies than those women who were not raped. Although the prospective nature of this study is noteworthy, its generalizability is limited by the fact that all women who participated in the study had histories of sexual victimization.

\subsection{Evidence suggesting that victimized women do not possess deficits in risk recognition}

In one of the first studies to assess risk perceptions and their relationship to victimization status, Breitenbecher (1999) conducted an innovative prospective investigation. At the start of the study, she had college student participants identify risk factors for sexual assault that were depicted in a video. Five months later she assessed for victimization status during the interim period. Whereas only about one-fourth of the risk factors were correctly identified by 
participants at the start of the study, participants' ability to identify the risk factors was not related to victimization status at the 5-month follow-up. In fact, subsequent investigations have suggested that women who are victimized do not evidence deficits in their perceptions of risk, but rather evidence different behavioral responses to a potential sexual assault situation. More specifically, in two similar studies it was found that college women who had histories of sexual assault believed themselves to be at a greater risk for sexual assault than women without sexual assault histories. However, these women also indicated a greater likelihood of using indirect methods of resistance, a lower likelihood of using active resistance strategies, and were more likely to indicate in a hypothetical situation that they would acquiesce to the potential perpetrator's request (Naugle, 2000; Norris et al., 1996).

In an unpublished study, Naugle (2000) had participants view three videotaped vignettes, each depicting different sexual assault scenarios. Victims of sexual assault (both childhood and adult victims) rated all three vignettes as riskier than women without such histories. These same women, who rated the scenarios as riskier, were more likely than non-victims to comply with the risky situation. Naugle (2000) concluded that victims possessed just as good, if not better, risk recognition capabilities. Victims, however, indicated that they would respond less assertively to an assault situation.

Further, in a retrospective experimental analogue study with a community sample, VanZile-Tamsen et al. (2005) specifically addressed whether women had difficulties identifying threat, responding to threat, or both. Participants read a scenario that described a situation that occurred at a party where a man followed a woman into a bedroom and engaged in inappropriate sexual advances. Following this, women rated their degree of discomfort in the hypothetical situation and indicated their anticipated responses. Results suggested that both women who were victimized in the past and non-victims evidenced equal levels of discomfort in response to the scenario. However, women victimized in childhood and adolescence or adulthood reported that they intended to engage in less direct verbal resistance than those who were either nonvictimized or victimized only during one developmental period. Although distinguishing between risk appraisal and behavioral responses to threat represents an improvement over prior investigations in this area, the retrospective nature of the design limits the findings.

In the most innovative study to date, Messman-Moore and Brown (in press) conducted a prospective investigation, in which these researchers followed university women for eight months. These researchers explored the relationship between women's ability to recognize and respond to sexual assault risk and the likelihood that they would be victimized during the follow-up period. At the beginning of the study, participants were asked to read a series of vignettes that contained risk factors for sexual assault. They were then asked to indicate when they would feel uncomfortable in the depicted situation and the point at which they would decide to leave the situation. Eight months following this initial assessment, participants were reassessed for victimization during the interim period. Participants' ratings of discomfort in the risky situations did not predict victimization status at the eight-month follow-up assessments. However, those participants who indicated that they would leave the risky situation at a later point were more likely to be victimized during the eight-month follow-up compared to those who indicated that they would leave the situation at an earlier point in time. The authors suggested that risk reduction efforts with women should be geared towards helping them to protect themselves in complex interpersonal situations, once threat is identified. It appears that regardless of victimization history, women identify threat in response to similar types of cues, however, their behavioral responses to these cues seem to be different (Messman-Moore \& Brown, in press).

\subsection{Explanations for inconsistencies}

Several studies have found that risk recognition is related to victimization status. Other studies, however, have found no such relationship and suggest that victimization status is related to women's behavioral responses to a potentially threatening situation, rather than their ability to recognize risk.

Several methodological differences could perhaps suggest possible reasons for discrepancies in results across studies. Sexual victimization was defined differently in several studies. As Messman-Moore and Brown (in press) pointed out, studies (Breitenbecher, 1999; Cue et al., 1996) which failed to find an association between risk recognition and victimization status, included very broad definitions of assault. A second explanation for inconsistencies across studies pertains to the fact that several studies utilized prospective designs, while other utilized retrospective designs. Additionally, studies have not been consistent in their use of vignettes. For example, some investigations used written vignettes and others used audio-taped vignettes. Written vignettes are problematic, in that participants, after realizing the scenario escalates into a rape, might purposefully mark that they recognized risk earlier than they truly did. A 
problematic element of both written and audio-taped vignettes is that participants are questioned about the point at which they perceive threat. The experimenters' questioning about when the participants "feel uncomfortable" or when they believe that the man has "gone too far" is likely to be an important cue for perceiving threat. In a real-life threatening situation, which is likely to take place in the context of some type of social interaction, there are likely no prompts for a potential victim. Further, the link between increased risk perception and past victimization may partially be a function of the fact that it is easier to imagine oneself in the victim role once having been victimized (HelwegLarsen \& Shepperd, 2001). However, if the scenarios depicted in the vignettes are not similar to the participants' victimization experience, the link between past victimization and increased risk perception might not be apparent.

Overall, generalizability of the vignettes and scenarios utilized in the vast majority of studies is questionable. Whereas a potential assault situation involves a complex series of factors that likely interact to lead to a woman's perception of risk, it is difficult to see how these types of complex interactions can actually be simulated with brief scenarios. Thus, these vignettes, which are purported to measure risk recognition, may not be capturing the true essence and complexities of real life social interactions.

\section{The relationship between situational factors and risk recognition}

\subsection{Alcohol use}

Other variables have been reported in the literature to affect an individual's ability to recognize risk in a sexual assault situation. Given that alcohol use is a part of many sexual assault experiences, in that both the offender and the victim are often intoxicated at the time of the assault (see Ullman, 2003 for a review), increased attention has been paid to the importance of alcohol use and its relationship to sexual assault risk perception (See Table 3 for a summary of relevant studies). Focus group discussions suggested that college women believed that alcohol would make it more difficult for them to identify risky situations (Norris et al., 1996). It has also been found that, in general, heavier drinkers, compared to light drinkers, perceived themselves to be at a greater risk to experience a sexual victimization (Gidycz, Loh, Lobo, Rich, Lynn, \& Pashdag, in press). Additionally, in a qualitative analysis of women's responses to sexual assault, Livingston and Testa (2000) reported that most women were also able to identify that a drinking man would pose a risk for sexual assault. Even though women were able to identify increased risk in an intoxicated man, most women, in response to a vignette, indicated that they would permit him to come into their homes. In general, it appears that women think that they are able to handle the risky situations that occur when alcohol is involved in their interactions with potential perpetrators (Parks et al., 1998).

Two laboratory studies have been conducted in which the participants were administered alcohol. In one study, Testa et al. (2000) utilized a sample of community women and placed them into one of three groups, an alcohol group, a placebo group, and a no alcoholic beverage group. Following this, participants read a vignette that described a risky situation, in which an intoxicated male acquaintance shows up at the participant's house after a night of drinking. The results suggested that compared to the non-drinking group, participants in the placebo and alcohol conditions perceived the man more positively. These same women also perceived greater benefits and fewer negative outcomes in engaging in behaviors that would likely increase their vulnerability to sexual aggression. Additionally, women in the placebo and alcohol groups anticipated that they would be more likely to engage in those risky behaviors. In a similar study, Davis (2000) found that in response to a vignette, alcohol consumption in a laboratory setting did decrease women's perceptions of cues that were indicative of sexual assault risk. Although these findings are noteworthy, in a qualitative analysis of the data from the participants in the Testa et al. (2000) study, it was found that none of the three drinking groups differed in their risk recognition capabilities (Livingston \& Testa, 2000).

\subsection{Summary and explanations of inconsistencies}

In general, although there are limited studies exploring the relationship between alcohol use and sexual assault risk recognition, it does appear that women, in general, believe that excessive alcohol use by both themselves and a potential perpetrator poses a risk for sexual victimization (Gidycz, Loh et al., in press; Norris et al., 1996; Parks et al., 1998). However, they also believed that they would be better able than other women to handle the risky situations if they were drinking (Norris et al., 1996; Parks et al., 1998). Thus, consistent with notions of comparative optimism, women who drink still believe that other women who drink are more vulnerable to sexual assault than themselves. 
Table 3

Summary of studies examining alcohol and risk recognition

\begin{tabular}{|c|c|c|c|}
\hline Authors & Sample & Variables $^{\mathrm{a}}$ and procedure & Findings \\
\hline Davis (2000) & $\begin{array}{l}62 \text { university } \\
\text { women; mean } \\
\text { age }=22.6\end{array}$ & $\begin{array}{l}\text { Women in the experimental group were administered } \\
\text { alcohol; utilized } 2 \text { written vignettes depicting casual and } \\
\text { serious dating relationship ending with the man } \\
\text { threatening and holding down the woman }\end{array}$ & $\begin{array}{l}\text { Alcohol decreased women's risk recognition and } \\
\text { increased their anticipated compliancy }\end{array}$ \\
\hline $\begin{array}{l}\text { Gidycz, Loh, } \\
\text { Lobo, } \\
\text { Rich, } \\
\text { Lynn, and } \\
\text { Pashdag } \\
\text { (in press) }\end{array}$ & $\begin{array}{l}372 \text { university } \\
\text { women; } 74 \% \\
\text { were } 18 \text { years } \\
\text { old }\end{array}$ & $\begin{array}{l}\text { Two questions created for this study asking amount of } \\
\text { alcohol typically consumed and frequency of use; one } \\
\text { question assessed participants estimated likelihood of } \\
\text { being sexually assaulted over a nine-week follow-up } \\
\text { period }\end{array}$ & $\begin{array}{l}\text { Women who were considered heavy drinkers perceived } \\
\text { themselves at greater risk for future sexual assault }\end{array}$ \\
\hline $\begin{array}{l}\text { Livingston } \\
\text { and Testa } \\
(2000)\end{array}$ & $\begin{array}{l}59 \text { community } \\
\text { women; mean } \\
\text { age }=23.16\end{array}$ & $\begin{array}{l}\text { Women were randomly assigned to the alcohol condition, } \\
\text { no alcohol condition, or placebo condition; utilized } \\
\text { written vignette that depicted an intoxicated male } \\
\text { acquaintance showing up at the participant's house after } \\
\text { she declined to hang out with him earlier on the phone; } \\
\text { after consuming alcohol and reading the vignette, } \\
\text { participants were instructed to write an ending to the } \\
\text { scenario; qualitative analyses }\end{array}$ & $\begin{array}{l}\text { Women in the three groups detected risk equally well; } \\
\text { women willing to accept these risks due to feelings of } \\
\text { control and potential social opportunities }\end{array}$ \\
\hline $\begin{array}{l}\text { Norris et al. } \\
\quad(1996)\end{array}$ & $\begin{array}{l}66 \text { sorority } \\
\text { women; mean } \\
\text { age }=19.2\end{array}$ & $\begin{array}{l}\text { Daily Drinking Questionnaire; focus group-qualitative } \\
\text { analyses }\end{array}$ & $\begin{array}{l}\text { Women believed that alcohol would make it more } \\
\text { difficult to identify risky situations, but also said that } \\
\text { they would remain in control }\end{array}$ \\
\hline $\begin{array}{l}\text { Testa, } \\
\text { Livingston, } \\
\text { and Collins } \\
(2000)\end{array}$ & $\begin{array}{l}59 \text { community } \\
\text { women; mean } \\
\text { age }=23.16\end{array}$ & $\begin{array}{l}\text { Women were randomly assigned to the alcohol condition, } \\
\text { no alcohol condition, or placebo condition; utilized } \\
\text { written vignette described above (Livingston \& Testa, } \\
\text { 2000); Cognitive Appraisal of Risky Events } \\
\text { Questionnaire; a measure was created for this study that } \\
\text { asked participants to rate the man on several different } \\
\text { dimensions; quantitative analyses }\end{array}$ & $\begin{array}{l}\text { Women in the alcohol and placebo condition viewed the } \\
\text { man more positively and perceived greater benefits and } \\
\text { fewer negative consequences than women in the no } \\
\text { alcohol condition; women in the alcohol and placebo } \\
\text { condition anticipated greater likelihood of engaging in } \\
\text { risky behaviors described }\end{array}$ \\
\hline
\end{tabular}

Summary of abbreviations: $\mathrm{CSA}=$ childhood sexual abuse, ASA= adult sexual assault.

${ }^{a}$ Other measures may have been used in the studies. However, for the purposes of this chart, only measures relevant to risk recognition and alcohol were included.

Although the laboratory studies conducted with actual alcohol use undoubtedly simulate what happens in the "real world" to a greater extent that just reading about a woman drinking alcohol as part of a vignette, it is interesting to note that quantitative and qualitative analyses of data conducted by Testa and co-workers (Livingston \& Testa, 2000; Testa et al., 2000) led to somewhat different results. In the qualitative analyses the vast majority of women identified risk concerns regardless of drinking status. However, drinking women still believed that they would be more likely to engage in risky behaviors and anticipated greater positive consequences from those behaviors. The authors tried to reconcile this different pattern of results by suggesting that alcohol might exert a greater effect on woman's responses to a threatening situation rather than on their ability to identify threat.

Indeed, it has been argued that alcohol might be linked with sexual assault both because it impairs a person's risk recognition as well as their ability to utilize effective physical resistance strategies and problem-solving skills (Nurius, 2000). Consistent with alcohol myopia theory (Steele \& Josephs, 1990), it has been suggested that although women might possess a general awareness that alcohol use increases their risk for sexual assault, that when drinking in a social situation, alcohol will decrease a woman's awareness of the more subtle inhibitory cues and increase their awareness of the affective and positive cues present in the situation. Alcohol thus acts as a cue to stimulate sexual interest and permissiveness, while simultaneously lessening the perceived gravity or severity of a potential sexual assault. These results imply that simply telling women that drinking increases their risk for sexual assault is not likely to change their behavior (Testa et al., 2000).

\subsection{Relationship between victim and perpetrator}

Although women correctly note that acquaintance rape is more common than stranger rape, it has been found that they generally fear stranger rape more than acquaintance rape (Hickman \& Muehlenhard, 1997). Although their fears 
of stranger rapes may be related to the fact that, in general, they tend to be more violent than rapes by acquaintances (Ellis, Atkeson, \& Calhoun, 1982; Koss, Dinero, Seibel, \& Cox, 1988), it has been noted that acquaintance rapes can be equally, or in some instances, more traumatic than stranger rapes (McCahill, Meyer, \& Fischman, 1979; Resick, 1983; Ullman \& Siegel, 1993 ). Moreover, the victim-perpetrator relationship may impact a woman's ability to perceive and respond to potential sexual assault threat (See Table 4, for a summary of relevant studies).

There have been three studies that have attempted to manipulate the victim-perpetrator relationship and explore its impact on a woman's perception of sexual assault risk. In the Davis (2000) laboratory study, where women were given alcohol and compared to a group of women who were not given alcohol, results suggested that women had greater awareness of risk with a new acquaintance compared to a date that they knew well, especially when they were drinking. Whereas the aforementioned study utilized a retrospective design, Messman-Moore and Brown (in press) found in their prospective design that participants' ability to identify risk in a stranger scenario did not predict subsequent rape over the eight-month follow-up period. In general, revictimization during the follow-up period was more closely tied to participants' hypothetical behavioral responses to the acquaintance rape, rather than the stranger rape scenario. It is likely that this occurred because women have been socialized to be on guard against strangers or with men that they do not know well. Further, in the study of VanZile-Tamsen et al. (2005) where vignettes were used to manipulate the level of prior intimacy between the potential victim and perpetrator, it was found that women's direct verbal and physical resistance decreased as the level of prior intimacy with a potential perpetrator increased.

The limited data in this area suggest that women seem to be more on guard with men who are strangers or those that they do not know well. Whereas it is clearly positive that women are cautious with men that they are either not acquainted with or are poorly acquainted with, these data need to be reconciled with the fact that it has been consistently shown that women are at the greatest risk to be sexually assaulted by intimates (Kilpatrick, Edmunds, \& Seymour, 1992; Russel, 1975), often men with whom they have previously had consensual sexual contact (Ullman, Karabatsos, \& Koss, 1999). Thus, risk reduction efforts and theoretical models of risk perception must take into consideration the complexities of the social interactions that often underlie the contexts in which sexual assaults occur (Nurius, 2000; Ullman, 2002; Yeater \& O’Donohue, 2002).

\section{Theoretical explanations of risk recognition and sexual assault}

The evidence is fairly clear that women in general perceive themselves as less likely than their peers to be sexually assaulted. This is most likely due to the fact that individuals tend to possess unrealistic perceptions of control and unrealistic perceptions of optimism (Taylor \& Brown, 1988). These inaccurate perceptions are maintained through cognitive-processing mechanisms that distort incoming information in a positive manner. These positive illusions are largely a comparative phenomenon, in that individuals tend to view themselves as less likely than other individuals to experience negative events (Weinstein, 1987). Women with histories of sexual assault, however, perceive themselves as more likely than their peers to be sexually assaulted. A recent study with sexual assault victims (Brown, MessmanMoore, Miller, \& Stasser, 2005) found that perceived similarity to a victim as well as psychological distress mediated the relationship between past victimization and heightened risk perceptions, ultimately reducing the occurrence of the optimism bias. These findings are consistent with social psychological theory, suggesting that trauma exposed individuals possess increased feelings of vulnerability for subsequent negative events (Weinstein et al., 2000). The findings reported in the literature are less consistent with regard to situational risk recognition and sexual assault. Although several studies have found that delayed risk recognition is related to sexual assault, when taking into account the methodological differences across studies, it appears that victimization status might be more strongly related to one's behavioral responses, rather than to perceptions of risk.

There may be a number of reasons why women do not respond assertively to situations even when they are able to perceive a threat. Nurius and Norris (1995) offer a cognitive-ecological model that encompasses both primary and secondary appraisals that help to explain why women may have difficulties responding effectively and assertively in particular situations, especially when they are acquainted with the potential perpetrator. Primary appraisals are women's initial assessment of risk. Women may have difficulty in recognizing risk early on in a situation because the positive elements associated with the situation often obscure the more subtle warning signs. Difficulties identifying risk are likely to be exacerbated when a woman is drinking, as the alcohol is likely to narrow her attention to the more salient, social cues available in the situation and decrease her attention towards the less salient risky cues. Secondary appraisals refer to the cost-benefit analyses in which women engage after recognizing that a situation poses a threat. 
Table 4

Summary of studies examining perpetrator intimacy and risk recognition

\begin{tabular}{|c|c|c|c|}
\hline Authors & Sample & Variables $^{\mathrm{a}}$ & Findings \\
\hline Davis (2000) & $\begin{array}{l}62 \text { university } \\
\text { women; mean } \\
\text { age }=22.6\end{array}$ & $\begin{array}{l}\text { Women in the experimental group were administered } \\
\text { alcohol; utilized } 2 \text { written vignettes depicting casual and } \\
\text { serious dating relationship ending with the man } \\
\text { threatening and holding down the woman }\end{array}$ & $\begin{array}{l}\text { Women had greater awareness of risk with new } \\
\text { acquaintance than with a date they knew well, } \\
\text { especially when drinking }\end{array}$ \\
\hline $\begin{array}{l}\text { Hickman and } \\
\text { Muehlenhard } \\
\text { (1997) }\end{array}$ & $\begin{array}{l}139 \text { university } \\
\text { women; mean } \\
\text { age }=19\end{array}$ & $\begin{array}{l}\text { All questions were created for this study, including how } \\
\text { likely participants were to be raped and how likely } \\
\text { college women were to be raped }\end{array}$ & $\begin{array}{l}\text { Women correctly noted that acquaintance rape is more } \\
\text { common than stranger rape, but generally feared } \\
\text { stranger rape more than acquaintance rape }\end{array}$ \\
\hline $\begin{array}{l}\text { Messman- } \\
\text { Moore and } \\
\text { Brown (in } \\
\text { press) }\end{array}$ & $\begin{array}{l}262 \text { university } \\
\text { women; mean } \\
\text { age }=19.18\end{array}$ & $\begin{array}{l}\text { SES; Risk Perception Survey - two written vignettes; } \\
\text { both ended with rape; one acquaintance in social setting; } \\
\text { the other stranger in non-social setting; both included } \\
\text { clear risk factors and ambiguous risk factors; } \\
\text { participants indicated when they felt uncomfortable and } \\
\text { when they would leave }\end{array}$ & $\begin{array}{l}\text { Women's ability to identify risk in both a stranger and } \\
\text { acquaintance scenario did not predict subsequent } \\
\text { victimization; behavioral response to the acquaintance } \\
\text { situation did predict victimization }\end{array}$ \\
\hline $\begin{array}{l}\text { VanZile- } \\
\text { Tamsen, } \\
\text { Testa, and } \\
\text { Livingston } \\
\text { (2005) }\end{array}$ & $\begin{array}{l}318 \text { community } \\
\text { women; mean } \\
\text { age }=23.97\end{array}$ & $\begin{array}{l}\text { Sexual Assertiveness Scale; Behavioral Intentions } \\
\text { (adapted from Norris, George, Stoner, \& Masters, 2002); } \\
\text { written vignette and risk appraisal scale: } 3 \text { written } \\
\text { vignettes; all the same scenario except that the intimacy } \\
\text { with the perpetrator varies in each (male friend, a date, } \\
\text { or a boyfriend); sexual advances escalate, ending with } \\
\text { the perpetrator pushing the woman on the bed }\end{array}$ & $\begin{array}{l}\text { Women's direct verbal and physical resistance } \\
\text { decreased as the level of prior intimacy with a } \\
\text { potential perpetrator increased }\end{array}$ \\
\hline
\end{tabular}

Summary of abbreviations: $\mathrm{CSA}=$ childhood sexual abuse, ASA = adult sexual assault.

${ }^{a}$ Other measures may have been used in the studies. However, for the purposes of this chart, only measures relevant to risk recognition and perpetrator intimacy were included.

Many women decide not to respond assertively, even in cases where they identify potential threat, because they worry about the negative social consequences that such responding may incur, such as rejection or embarrassment. Empirical evidence suggests, for example, that women were more likely to report that they responded assertively to a sexual assault situation, rather than diplomatically when they were less concerned about preserving the relationship (Nurius, Norris, Young, Graham, \& Gaylord, 2000).

Thus, it has been suggested that a typical sexual assault takes place in situations (e.g., bars, parties) where women often know that there is some risk involved. At the same time, however, the potential for establishing social relationships exist in these contexts (Testa et al., 2000). The crucial task for women is to be able to keep themselves safe in light of the conflicting goals in these settings. It is important to keep in mind, however, that in an acquaintance rape situation, threat often emerges in an incremental manner and women must appraise the threatening, often ambiguous, situations and decide whether to respond defensively. (Nurius et al., 2000). In a potential acquaintance assault situation, women must weigh the costs and benefits of responding to a potential threatening situation. As stated by Nurius et al. (2000), "This situation puts a woman in the unfortunate predicament of weighting social versus safety costs" (pg. 203).

\subsection{Risk recognition and sexual revictimization}

Other researchers have focused on the mediating role of psychological distress. It has been theorized that when a woman's psychological functioning is impaired, it is more difficult for her to perceive and/or respond to threat in a situation. Although this could be true for all women, this reasoning has been often used to explain revictimization. Several psychologists have theorized that dissociative and numbing symptoms render women less able to perceive danger in their environment and are thus more likely to be revictimized (Chu, 1992; Kluft, 1990). Cloitre, Scarvalone, and Difede (1997) further suggested that dissociative women have difficulty in recognizing and classifying emotional states and therefore cannot recognize internally produced warning signs when confronted with risky situations.

It is important to keep in mind that no two victims share identical experiences. Therefore, when attempting to identify the processes through which women perceive and respond to risk it is difficult to make predictions for individual women. When attempting to make predictions about risk perceptions in victims of sexual assault, it is important to consider whether they labeled their past victimization as abuse, the severity of the past abuse, and the length of time since the assault. These factors are all likely to impact women's ability to identify and respond to a future 
victimization experience. Data, for example suggest that, whereas a past trauma reduces the optimism bias, this reduction of the optimism bias tends to dissipate over time (Dunning, Heath, \& Suls, 2004). These potential important mediators have been ignored in past attempts to understand risk perception in past victims of sexual assault.

\section{Conclusion}

\subsection{Implications for intervention}

Taken together, this body of literature has important implications for sexual assault risk reduction programming. Clearly, women exhibit an optimistic bias whereby they believe that they are less likely than their peers to encounter sexual aggression Even if they are able to identify their risky behaviors, women still believe that they are better able than others to handle these situations. These results imply that any intervention designed to reduce women's risk for sexual victimization must strive to address the unrealistic optimism that women experience when judging their risk for sexual assault. However, research has consistently shown that across various types of health-related problems (e.g., heart disease, automobile injury), this optimistic bias is fairly resistant to change. In one study, for example, four different interventions were utilized in attempts to reduce the optimistic bias that existed for various health-related behaviors. None of these interventions were successful (Weinstein \& Klein, 1995). In fact, Weinstein and Klein (1995) concluded that "people prefer to believe that their risk is below average and are reluctant to believe anything else" (p. 10).

Research that has examined potential moderators of the optimism bias is important to consider when attempting to reduce this cognitive distortion in the context of risk reduction efforts with women. It has been found that unrealistic optimism tends to attenuate when people compare themselves to targets that are more specific, closer, and similar (Helweg-Larsen \& Shepperd, 2001; Stapel \& Velthuijsen, 1996). In the case of victims of sexual assault, all too commonly individuals try to distance themselves from the prototypical victim and may hold erroneous beliefs about the "typical victim." Thus, it seems likely that interventions designed to reduce women's risk for sexual victimization need to continually utilize examples and situations that are particularly salient for the program participants. Participants in risk reduction programs must leave the program believing that sexual assault can happen to any woman and to view themselves as having more in common with women who are victimized. It is important that women not separate themselves from victims, as the empirical data have consistently failed to find personality or attitudinal factors that distinguish victims from non-victims (Koss, 1985). Thus, rather than having women compare their chances of being victimized to the average woman, data suggests that the optimistic bias is reduced when the target is individualized and close contact is established. Presenting program participants with models of victims (either through video tapes or presentations) may decrease the optimistic bias through allowing women to reduce the differences between themselves and an actual victim. When differences between victims and program participants are minimized, it is likely more difficult to engage in comparisons that are ego enhancing (see Weinstein, 1989).

Further, interventions that address other health-related behaviors have found that in addition to providing the participants with self-relevant information that the optimistic bias can be reduced when the information provided to participants is also vivid (Stapel \& Velthuijsen, 1996). Because it has been shown that personal experience with negative events reduces the optimistic bias (Weinstein, 1989), interventions that seek to personalize the risk information are thought to be more effective because they have some of the elements of direct experience. For example, vivid information, much like direct experience, attracts and holds the attention of others because it is detailed, emotionally interesting, and thought-provoking (Stapel \& Velthuijsen, 1996). Opportunities to engage in specific discussions about the types of risky situations that individual participants encounter rather than a more general discussion of risk factors should reduce the likelihood of the optimistic bias in sexual assault risk reduction programming (see Marx et al., 2001; Gidycz, Rich et al., in press, for examples of programming efforts along these lines).

Along with decreasing the optimism bias among program participants, programs must address issues related to helping women respond to threat once it is identified. Consistent with social-cognitive models of risk perception, it is important to help women address and cope with the many barriers that they encounter when faced with a potentially threatening situation. Women need to be aware of their interest in a potential relationship with a man and, at the same time, be cognizant of his potential for sexual aggressiveness. It is likely that providing women with realistic scenarios or role plays, where the conflicting goals of safety and relationship initiation are addressed, may help women to be 
better equipped to deal with real-life threatening situations. We agree with Nurius et al. (2000) that programming with women must be careful to not underestimate the potential costs that women experience when in a potential threatening situation. Simulating and presenting scenarios to women, where their potential confusion and concerns can be taken into account and discussed, will help them to be better prepared to deal with these ambiguous situations. Additionally, there are a number of characteristics that perpetrators have been found to possess (e.g., inappropriate touching of women, high needs for control) that need to be presented to women in the context of programming efforts to help them to better identify risky men.

It is also important that interventions provide women with the skills necessary to respond assertively in a sexual assault situation, especially in situations where the risk cues are more subtle. Given that data clearly suggest that assertive responding including forceful physical resistance, and forceful verbal resistance are related to rape avoidance (e.g., Ullman, 1998; Ullman \& Knight, 1993), women need to be taught specific skills to defend themselves against threatening situations. We believe that women need to be provided with the opportunity to practice a range of physical self-defense tactics, including verbal assertiveness skills and physical self-defense tactics (Gidycz, Rich et al., in press). Women need to be taught to increase the forcefulness of their responses based on the men's response to their resistance. Because there are many societal pressures that make it difficult for women to engage in defensive action, programs need to train women how to utilize the most effective resistance strategies when faced with a sexual assault situation. Greater attention needs to be given to the process of quickly recognizing risk and responding effectively, especially in an acquaintance assault situation (Rozee \& Koss, 2001).

Whereas the above-reviewed information is relevant for women in the general population, it is important to keep in mind that often in programs geared towards a wide audience (e.g., a group of college students), there is likely to be a number of survivors in the audience and their special needs must be addressed. Although sexual assault survivors might evidence less of an optimism bias than women without assault histories, and thus see their chances of being victimized more realistically, they may also experience lowered levels of self-efficacy in their ability to respond assertively (Bryant, 2001). Further, previously assaulted women may experience aftereffects that compromise their ability to identify a threatening situation, in addition to making them appear more vulnerable to potential perpetrators who are selecting specific targets Although many survivors of sexual assault are likely to benefit from the behavioral skills that are presented, it is important to keep in mind that some survivors may be in need of more specialized treatment programs to address the post-traumatic symptomatology associated with earlier abusive experiences. At the very least, all program evaluation studies of risk reduction efforts should take into consideration how their participants' past histories of abuse is related to their outcome evaluations. We believe that a sense of empowerment can be instilled in all women by helping them practice and plan to use assertive behavioral responses that they would effectively utilize in a sexual assault situation.

\subsection{Suggestions for future research}

Although researchers are beginning to gain a better understanding of risk recognition and sexual assault, further research is needed in a number of areas. Perhaps one of the most important areas yet to be investigated pertains to the mechanisms underlying the relationship between risk recognition and subsequent behavioral responding. Several studies have found that women recognize risk in a hypothetical vignette much earlier than they say that they would leave the situation. Whereas some researchers have designed scales to measure the barriers that women experience when trying to decide whether to respond assertively or not (Nurius et al., 2000), it would likely be very informative to conduct qualitative analyses with women to better understand how women's perceptions of risk can be transformed into effective defensive action.

The vignettes often utilized in this type of research are problematic in that researchers do not really know if these instruments are capturing the true complexities of a sexual assault situation, as very little validity information exists for these measures. In fact, it is highly likely that the external validity of the vast majority of vignettes utilized is questionable. For example, in the Soler-Baillo et al.'s (2005), study where participants' heart rates were monitored as an audio-taped interaction between a man and a woman escalated to a rape, it was found that the later segments of the tape where the man was the most aggressive did not produce physiological activity that was much greater than baseline for either the victims or non-victims. The researchers suggested that perhaps the participants' realized the contrived nature of the video tape. Additionally, it is important to note that none of the studies utilizing vignettes has ever included a control scenario that was not risky. Without a comparison, low-risk scenario, the possibility that participants 
do not evidence similar kinds of responses to low-risk situations cannot be ruled out. We understand that it is incredibly difficult to assess what actually happens in a threatening situation, and that it would be impossible to gather first-hand information about what actually occurs in a sexual assault situation. In light of this, it might be beneficial to interview sexual assault survivors soon after an assault in order to explore more fully the social decision-making processes that occur in these types of situations.

It has been suggested in this review article that interventions designed to reduce women's risk for sexual assault should attempt to counteract a woman's optimistic bias about her risk for victimization. Whereas there has been work conducted in other areas that attempts to manipulate the presentation of risky information in order to see its effect on the optimistic bias (e.g., Weinstein \& Klein, 1995), researchers have not explored how various ways of presenting information about sexual assault risk might impact the optimistic bias. Following, it seems important that research should be conducted with regards to not only the most effective way to do this in sexual assault interventions, but to assess the effects reducing this bias might have on a woman's ability to respond to a threatening situation as well as on other aspects of mental health.

Alcohol consumption and the victim-offender relationship are important components of the risk recognition and the behavioral response process that have been examined (e.g., Testa and Livingston, 2000; VanZile-Tamsen et al., 2005). It has also been suggested that particularly for past victims of sexual assault underlying psychological distress is another important variables that most likely affects the risk recognition and behavioral response process. To date, however, the vast majority of studies in this area have been retrospective, making it difficult to draw causal conclusions. Further, as suggested previously, it is likely that various personal and situational aspects related to a woman's victimization experience, such as the severity of the experience, the length of time since it occurred, and whether she labeled it as an assault are likely to impact her perception of further risk. Future studies would benefit from taking a longitudinal approach and including in their analyses a greater number of factors that are likely to both impact a woman's perception of risk as well as her response to threatening situations.

Above all, research efforts must continue to try to better understand sexual perpetration so that programming with men can significantly reduce, if not eliminate, the occurrence of sexual violence. Whereas the body of literature reviewed has contributed greatly to our understanding of how, and under what circumstances, women perceive their own risk to be victimized, with one exception to date (Gidycz, Warkentin, Orchowski, \& Dicken, 2004), men's perceptions of their risk to perpetrate, and how they might deal with these risky situations has been virtually unexplored. Future work attempting to explore how men perceive their risk to be aggressive would be useful for intervention efforts. However, until effective interventions have been identified for men, it is our obligation as researchers and clinicians to educate women to recognize risk and teach them how to respond assertively and effectively.

\section{References}

Brecklin, L. R., \& Ullman, S. E. (2002). The roles of victim and offender alcohol use in sexual assaults: Results from the National Violence against Women Survey. Journal of Studies on Alcohol, 63, 57-64.

Breitenbecher, K. H. (1999). The association between the perception of threat in a dating situation and sexual victimization. Violence and Victims, 14 , $135-146$.

Brener, N. D., McMahon, P. M., Warren, C. W., \& Douglas, K. A. (1999). Forced sexual intercourse and associated health-risk behaviors among female college students in the United States. Journal of Consulting and Clinical Psychology, 67, 252-259.

Brown, A. L., Messman-Moore, T. L., Miller, A. G., \& Stasser, G. (2005). Sexual victimization in relation to perceptions of risk: Mediation, generalization, and temporal stability. Personality and Social Psychology Bulletin, 31, 963-976.

Bryant, N. L. (2001). Child sexual abuse and its relationship to perceived vulnerability, powerlessness, self-efficacy, and sexual assault. (Doctoral dissertation, Ohio University, 2001). Dissertation Abstracts International, 61, 4973.

Chu, J. A. (1992). The revictimization of adult women with histories of childhood abuse. Journal of Psychotherapy Practice and Research, 1, $259-269$.

Cloitre, M., Scarvalone, P., \& Difede, J. (1997). Posttraumatic stress disorder, self- and interpersonal dysfunction among sexually retraumatized women. Journal of Traumatic Stress, 10, 437-451.

Cue, K. L., George, W. H., \& Norris, J. (1996). Women's appraisals of sexual-assault risk in dating situations. Psychology of Women Quarterly, 20, 487-504.

Davis, K. L. C. (2000). Women's perceptions of and responses to sexual aggression: The alcohol myopia and anxiolysis-disinhibition theories (Doctoral dissertation, University of Washington). Dissertation Abstracts International, 62, 3560.

Dunning, D. H., Heath, C., \& Suls, J. M. (2004). Flawed self-assessment. Psychological Science in the Public Interest, 5, $69-106$.

Ellis, E. M., Atkeson, B. M., \& Calhoun, K. S. (1982). An examination of differences between multiple- and single-incident victims of sexual assault. Journal of Abnormal Psychology, 91, 221-224. 
Finkelhor, D. (1979). Sexually victimized children. New York: Free Press.

Gidycz, C. A., Hanson, K., \& Layman, M. J. (1995). A prospective analysis of the relationships among sexual assault experiences. Psychology of Women Quarterly, 19, 5-29.

Gidycz, C. A., Loh, C., Lobo, T., Rich, C., Lynn, S. J., \& Pashdag, J. (in press). Reciprocal relations among alcohol use, risk perception, and sexual victimization: A prospective analysis. Journal of American College Health.

Gidycz, C. A., Rich, C., King, C., Orchowski, L., \& Miller, A. L. (in press) An evaluation of a self-defense and risk reduction program for college women: A prospective study. Psychology of Women Quarterly.

Gidycz, C. A., Warkentin, J., Orchowski, L., \& Dicken, E. (2004, November). Men's alcohol use and perceptions of risk for committing a sexual assault. Poster presented at the meeting of the Associating for the Advancement of Behavior Therapy, New Orleans, LA.

Helweg-Larsen, M., \& Shepperd, J. A. (2001). Do moderators of the optimistic bias affect personal or target risk estimates? A review of the literature. Personality and Social Psychology Review, 5, 74-95.

Hickman, S. E., \& Muehlenhard, C. L. (1997). College women's fears and precautionary behaviors relating to acquaintance rape and stranger rape. Psychology of Women Quarterly, 21, 527-547.

Kilpatrick, D. G., Edmunds, C. N., \& Seymour, A. K. (1992). Rape in America: A report to the nation. Arlington, VA: National Crime Center.

Kluft, R. P. (1990). Dissociation and subsequent vulnerability: A preliminary study. Dissociation: Progress in the Dissociative Disorders, 3, $167-173$.

Koss, M. P. (1985). The hidden rape victim: Personality, attitudinal, and situational characteristics. Psychology of Women Quarterly, 9, $193-213$.

Koss, M. P., Dinero, T. E., Seibel, C. A., \& Cox, S. L. (1988). Stranger and acquaintance rape: Are there differences in the victim's experience? Psychology of Women Quarterly, 12, 1-24.

Koss, M. P., Gidycz, C. A., \& Wisniewski, N. (1987). The scope of rape: Incidence and prevalence of sexual aggression and victimization in a national sample of higher education students. Journal of Consulting and Clinical Psychology, 55, 162-170.

Livingston, J. A., \& Testa, M. (2000). Qualitative analysis of women's perceived vulnerability to sexual aggression in a hypothetical dating context. Journal of Social and Personal Relationships, 17, 729-741.

Marx, B. P., \& Gross, A. M. (1995). An analysis of two contextual variables. Behavior Modification, 19, 451-463.

Marx, B. P., Calhoun, K. S., Wilson, A. E., \& Meyerson, L. A. (2001). Sexual revictimization prevention: An outcome evaluation. Journal of Consulting and Clinical Psychology, 69, 25-32.

McCahill, T. W., Meyer, L. C., \& Fischman, A. M. (1979). The aftermath of rape. United States: DC Heath and Company.

Messman-Moore, T. L., \& Brown, A. L. (in press). Risk perception, rape, and sexual revictimization: A prospective study of college women. Psychology of Women Quarterly.

Naugle, A. E. (2000). Identifying behavioral risk factors for repeated victimization using video-taped stimulus materials. (Doctoral dissertation, University of Nevada, Reno). Dissertation Abstracts International, 61, 1091.

Norris, J., George, W. H., Stoner, S. A, \& Masters, N. T. (2002, August). Child abuse and adult revictimization: Alcohol's mediating influence. Paper presented at the annual meeting of the American Psychological Association, Chicago, IL.

Norris, J., Nurius, P. S., \& Dimeff, L. A. (1996). Through her eyes: Factors affecting women's perception of and resistance to acquaintance sexual aggression threat. Psychology of Women Quarterly, 20, 123-145.

Norris, J., Nurius, P. A., \& Graham, T. L. (1999). When a date changes from fun to dangerous: Factors affecting women's ability to distinguish. Violence Against Women, 5, 230-250.

Nurius, P. S. (2000). Risk perception for acquaintance sexual aggression: A social-cognitive perspective. Aggression and Violent Behavior, 5, 63-78.

Nurius, P. S., \& Norris, J. (1995). A cognitive ecological model of women's responses to male sexual coercion in dating. Journal of Psychology and Human Sexuality, 8, 117-139.

Nurius, P. S., Norris, J., Dimeff, L. A., \& Graham, T. L. (1996). Expectations regarding acquaintance sexual aggression among sorority and fraternity members. Sex Roles, 35, 427-444.

Nurius, P. S., Norris, J., Young, D. S., Graham, T. L., \& Gaylord, J. (2000). Interpreting and defensively responding to threat: Examining appraisals and coping with acquaintance sexual aggression. Violence and Victims, 15, 187-298.

Parks, K. A., Miller, B. A., Collins, R. L., \& Zetes-Zanatta, L. (1998). Women's description of drinking in bars: Reasons and risks. Sex Roles, 38, 701-771.

Resick, P. A. (1983). The rape reaction: Research findings and implications for intervention. Behavior Therapist, 6, $129-132$.

Rich, C. L. Combs-Lane, A. M., Resnick, H. S., \& Kilpatrick, D. G. (2004). Child sexual abuse and adult sexual revictimization. In L. J. Koenig (Ed.), From child sexual abuse to adult sexual risk: Trauma, revictimization, and intervention (pp. 49-68). Washington, DC: American Psychological Association.

Rozee, P. D., \& Koss, M. P. (2001). Rape: A century of resistance. Psychology of Women Quarterly, 25, 295-311.

Russel, D. E. (1975). The politics of rape: The victim's perspective. New York: Stein and Day.

Shepperd, J. A., Carroll, P., Grace, J., \& Terry, M. (2002). Exploring the causes of comparative optimism. Psycholgica Belgica, $42,65-98$.

Soler-Baillo, J. M., Marx, B. P., \& Sloan, D. M. (2005). The psychophysiological correlates of risk recognition among victims and non-victims of sexual assault. Behavior Research and Therapy, 43, 169-181.

Stapel, D. A., \& Velthuijsen, A. S. (1996). "Just as if it happens to me": The impact of vivid and self-relevant information on risk judgments. Journal of Social and Clinical Psychology, 15, 102-119.

Steele, C. M., \& Josephs, R. A. (1990). Alcohol myopia: Its prized and dangerous effects. American Psychologist, 45, $921-933$.

Taylor, S. E., \& Brown, J. D. (1988). Illusion and well-being: A social psychological perspective on mental health. Psychological Bulletin, 1, $193-210$.

Testa, M., Livingston, J. A., \& Collins, R. L. (2000). The role of women's alcohol consumption in evaluation of vulnerability to sexual aggression. Experimental and Clinical Psychopharmacology, 8, 185-191. 
Tjaden, P., \& Thoennes, N. (2000). Full report of the prevalence, incidence, and consequences of violence against women: Findings from the national violence against women survey. Washington, DC: U. S. Department of Justice, National Institute of Justice NCJ Publication No. 183781.

Ullman, S. E. (1998). Does offender violence escalate when rape victims fight back? Journal of Interpersonal Violence, 13, $179-192$.

Ullman, S. E. (2002). Rape avoidance: Self-protection strategies for women. In P. A. Schewe (Ed.), Preventing violence in relationships. Interventions across the life span. Washington, DC: American Psychological Association.

Ullman, S. E. (2003). A critical review of field studies on the link of alcohol and adult sexual assault in women. Aggression and Violent Behavior, 8 , 471-486.

Ullman, S. E., Karabatsos, G., \& Koss, M. P. (1999). Alcohol and sexual assault in a national sample of college women. Journal of Interpersonal Violence, 14, 603-625.

Ullman, S. E., \& Knight, R. A. (1993). The efficacy of women's resistance strategies in rape situations. Psychology of Women Quarterly, 17, 23-39.

Ullman, S. E., \& Siegel, J. M. (1993). Victim-offender relationship and sexual assault. Violence and Victims, 8, 121-134.

VanZile-Tamsen, C., Testa, M., \& Livingston, J. A. (2005). The impact of sexual assault history and relationship context on appraisal of and responses to acquaintance sexual assault risk. Journal of Interpersonal Violence, 20, 813-832.

Wilson, A. E., Calhoun, K. S., \& Bernat, J. A. (1999). Risk recognition and trauma-related symptoms among sexually revictimized women. Journal of Consulting and Clinical Psychology, 67, 705-710.

Weinstein, N. D. (1980). Unrealistic optimism about future life events. Journal of Personality and Social Psychology, 39, 806-820.

Weinstein, N. D. (1987). Unrealistic optimism about susceptibility to health problems: Conclusions from a community wide-sample. Journal of Behavioral Medicine, 10, 481-500.

Weinstein, N. D. (1989). Effects of personal experience on self-protective behavior. Psychological Bulletin, 105, 31-50.

Weinstein, N. D., \& Klein, W. M. (1995). Resistance of personal risk perceptions to debiasing interventions. Health Psychology, 14, 132-140.

Weinstein, N. D., Lyon, J. E., Rothman, A. J., \& Cutie, C. L. (2000). Changes in perceived vulnerability following natural disaster. Journal of Social and Clinical Psychology, 19, 372-395.

Whitmire, L. E., Harlow, L. L., Quina, K., \& Morokoff, P. J. (1999). Childhood trauma and HIV. Philadelphia: Brunner/Mazel.

Yeater, E. A., \& O'Donohue, W. (2002). Sexual revictimiztion: The relationship among knowledge, risk perception, and ability to respond to highrisk situations. Journal of Interpersonal Violence, 17, 1135-1144. 